\title{
GPR15 wt Allele
}

National Cancer Institute

\section{Source}

National Cancer Institute. GPR15 wt Allele. NCI Thesaurus. Code C140246.

Human GPR15 wild-type allele is located in the vicinity of 3q11.2 and is approximately $1 \mathrm{~kb}$ in length. This allele, which encodes G-protein coupled receptor 15 protein, is involved in the migration of regulatory $\mathrm{T}$-cells (Tregs). 